\title{
The Effectiveness of Science Project Learning based on Entrepreneurship Model to Improve Elementary Students' Collaborative Skills
}

\author{
Ishmatun Naila \\ Elementary Teacher Education Program, Muhammadiyah University of Surabaya, Surabaya, Indonesia \\ $\bowtie$ ishmatun@fkip-um.surabaya.ac.id
}

\begin{abstract}
Collaborative skills are among four essential life skills that students need to master in the $21^{\text {st }}$ century. The fifth-grader of elementary school students' low collaborative skills encourages the researcher to develop a science project learning model with an entrepreneurship model to improve these skills. The purpose of this research is to determine the effectiveness of the learning model by implementing quasi-experiment, with one group pretest and post-test design. Data analysis methods used were t-test, N-Gain analysis, and oneway analysis of variance (One Way Anova) to determine if there was an improvement after learning. The results of the analysis using the t-test showed a significant increase in pre- and post-test ( $p<0.05$ ), with post-test values better than pre-test (negative $t$ ). The results of the $\mathrm{N}$ Gain analysis showed the average increase in student scores in the high category $(\geq 0.70)$, and the results of the analysis of the one-track variance showed no difference in each group ( $p$ > 0.05). In general, the findings indicate that the learning model is effective in improving the collaborative skills of elementary school students.
\end{abstract}

Keywords: collaborative skills, elementary education, entrepreneurship, project learning, science subject

How to Cite: Naila, I. (2020). The Effectiveness of Science Project Learning based on Entrepreneurship Model to Improve Elementary Students' Collaborative Skills. Mimbar Sekolah Dasar, 7(3), 348-361. doi:https://doi.org/10.17509/mimbar-sd.v7i3.28676.

INTRODUCTION Almost all the aspects of life keeps changing and do not stop; it goes faster (Skiba, 2012) instead. Those who lacked the skills should be ready to be replaced by a machine (Shum, Kodama, \& Shibata, 2020). To survive in the future, students, especially elementary students, should be equipped with various essential skills, namely Creativity \& Innovation, Critical Thinking \& Problem Solving, Collaborative, and Communication (4C) (Trilling \& Fadel, 2010). At the level of elementary education, those skills are not necessarily required in the high level; it started by incorporating the aspects into everyday learning. One of the $4 \mathrm{C}$ skills, namely collaboration, is interaction and a personal lifestyle in which individuals are responsible for their actions, including learning and respecting their peers' abilities and contributions (Song, 2018). The difference between cooperation and collaboration is that cooperation is an interaction structure that is designed to facilitate a specific final product or goal through people working together in groups. Nowadays, collaborative skills have become crucial, since they can accelerate group work. Various students with varied backgrounds and skills are working together to achieve one big goal by doing what they are talented at. 
Ishmatun Naila, The Effectiveness of Science Project Learning based on Entrepreneurship Model...

Collaborative learning is done through students' interactive involvement in activities while at the same time, engaging them in social learning experiences. Research by Cho and Quint (Cho \& Lim, 2017; Quint \& Condliffe, 2018) states that such an approach positively affects learning outcomes. One of the learning models that can be used to improve collaborative skills is Project-Based Learning (PjBL) (Trilling, 2010). One of the policies in implementing elementary curricula in Indonesia, $\mathrm{K}-13$, is a change in the learning paradigm from teachercentered to student-centered (Yonanda, Yuliati, \& Saputra, 2019). To achieve studentcentered learning, teachers are expected to apply a scientific approach in learning activities, namely, observe, ask questions, gather information, reason/associate, and communicate. Four learning models that use this scientific approach are: Discovery and Inquiry Learning, Problem Solving, Problem-Based Learning, and Project-Based Learning.

Project-based learning has become the primary strategy used by most of the best education systems in the world. Authentic learning that addresses $21^{\text {st }}$ century skills is what Project-Based Learning (PjBL) offers (Rubrica, 2018). According to Quint \& Condliffe (2018), there is a rapid increase in the use of the PjBL teaching method in science classrooms. The benefit for students is that they can actively participate in project-based learning in class, where they are asked to work collaboratively to solve problems, and then discuss and reflect on what they have learned (Gu, Chen, Zhu, \& Lin, 2015).

Collaborative project-based learning is recognized as a component of several higher education courses, as it appears to motivate students and keep them active in the learning process. Collaborative PjBL is required so that tutors can intervene and guide students flexibly: by encouraging them to develop independent solutions and keeping their efforts and activities targeted for learning goals. On the other hand, students need to develop essential skills in finding and analyzing information and communication and time management.

Industry Revolution 5.0, which is on its way happening to the world, requires humans to continue to change before being changed (Schwab, 2017). Much different from before, this 5.0 Industrial Revolution has a broader scale of complexity and scope. Various new digital technologies that continue to shift humans' role in their profession massively cannot be denied that they will continue to develop. With the increase in the number of school graduates, Indonesia's unemployment rate will also increase if school graduates do not have skills in the field of entrepreneurship.

Entrepreneurship-based learning for students aged 11 years is the right time (Hassi, 2016). His research was designed to identify appropriate and relevant goals that need to be pursued through entrepreneurship activities targeting elementary school children. He assessed the effectiveness of early entrepreneurship education. The research findings found that children aged 11-12 years are at a sufficient period to develop self-efficiency, the non-cognitive skills 
needed to become entrepreneurs (Polat, 2018). So, this $5^{\text {th }}$ grade students are perceived to be the right time for combining an entrepreneurship approach with a project learning model (Ghazi, Ullah, \& Jan, 2016).

The results of preliminary research at an elementary school in Surabaya, Indonesia, through observations in fifth-grade science class showed that (1) students still lacked collaboration in solving the problems given by the researcher as indicated by the results of the pre-test collaborative skills with a mean value below 75 and the score for each indicator between 1-2 (maximum score of 4); (2) in the learning material for the water cycle on the theme of environment, it did not use learning media; so (3) the given project had not been oriented towards a specific new skill. These problems have an impact on student activities in class, including: (1) students who actively expressed opinions were only a few; (2) there was a lack of social activities in the form of interactions and contributions in class, so that students were not accustomed to collaborating in a project. One of the problems that must be resolved immediately is the students' ability to collaborate.

In recent years, there has been growing recognition of vital links between project-learning and entrepreneurship approach (Harms, 2015; Sabahi \& Parast, 2020; Seikkula-Leino, Ruskovaara, Ikavalko, Mattila, \& Rytkola, 2010; Shepherd, Haynie, \& Patzelt, 2013). However, those studies have not combined science project learning with entrepreneurship. Most of them are the social topic. It is interesting knowing that some survey data suggest that more young people, in both developed and developing countries, increasingly view entrepreneurship as the right choice for a career option in this era (Guthrie, 2014). Hence, this research seeks to find out if science project learning can be a good combination with the entrepreneurship approach to play a significant role in fostering the collaborative skills of elementary students. Based on the aforementioned background and previous research, this research aimed to solve problems in group learning activities/work on assignments in groups to improve student collaborative skills while fostering an entrepreneurial spirit.

\section{METHOD}

This research employs quasi-experimental model for science learning conducted to $5^{\text {th }}$ grader of elementary school. A quasi-experimental model aims at predicting the conditions achieved by pure experimental research, without controlling or manipulating all the relevant variables (Ramdan, Hanifah, \& Isrokatun, 2019). Also, this type of research is frequently used to evaluate educational programs when a random assessment is not possible (Putri, Rahayu, Muqodas, \& Wahyudy, 2020). The subjects were 30 fifth grade students from three different classes of an elementary school in Surabaya, Indonesia. 
Ishmatun Naila, The Effectiveness of Science Project Learning based on Entrepreneurship Model...

According to Astutik \& Prahani (2018) and Fuad, Alfin, Fauzan, Astutik, \& Prahani (2019), the effectiveness of the learning model is determined based on: 1) Significant increase in the score between the pre-test and post-test of the students' collaborative skills, (2) The n-gain average is determined at least on the medium improvement criterion, (3) The consistency of the average n-gain score of the students' collaborative skills, and (4) Student's response is at least positive enough.

\section{Research Procedure}

This research design used was one group pre-test and post-test design (Fraenkel \& Wallen, 2012), which was implemented to 30 students of $5^{\text {th }}$-grade elementary school.

$$
01 \quad \mathrm{O} \quad \mathrm{2}
$$

O1: Pre-test score, O2: Post-test score, X: Science Project Learning based on Entrepreneurship Model.

Before the research, firstly, the researcher set up teaching instruments that covered these components: The natural science learning instruments are syllabus, learning implementation plan, student activity sheet, textbook, collaboration evaluation sheet, and student's response questionnaire (valid and reliable). The validity of those teaching instruments from science project learning model was then assessed by the biology and elementary education experts in terms of the content and construct. For the teaching instruments to be implemented, the learning instruments had to meet the valid and reliable requirements. To find out students' collaborative skills, this study begins with giving a pre-test of collaborative skills (O1) through several collaborative skills questions with indicators proposed by Hermawan et al., (2017). After that, they were using science project learning based on the entrepreneurship model. After all the learning process completed, all students are given a collaborative skills' post-test with the same material and problems as the pre-test questions.

\section{Research Analysis}

Collaborative skills of elementary students are analyzed based on the assessment conducted before and after applying science project learning based on entrepreneurship approach to $5^{\text {th-grade }}$ of environmental science subjects. Pre-test, post-test, and n-gain of collaborative skills were analyzed using inferential statistics with the help of IBM SPSS software 25 . The N-gain was determined using the equation: $n$-gain = (post-test score - pre-test score) or (maximum score - pre-test score), with criteria: (1) if n-gain $\geq .7$ (high), (2) if . $3<\mathrm{n}$-gain <.7 (medium), and (3) if $n$-gain $\leq .3$ (low). The inferential statistical test with the science project learning model used ANOVA test. 


\section{RESULTS}

Extensive trials conducted in classes $5 \mathrm{~A}, 5 \mathrm{~B}$, and $5 \mathrm{C}$ with 30 students in each class. The trial was conducted by providing the learning process of three meetings to know the learning devices' practicality and effectiveness. The implementation of learning on trial was extensive, the author as a teacher and five people as observers. Each observer was tasked to observe and assess the implementation of the lesson plan and student activities during the learning process. The learning process was descriptively qualitatively analyzed, while the learning results were analyzed in quantitative description.

The analysis of collaborative skills results was carried out based on data obtained from the collaborative skills test of fifth grade students and analyzed using t-test and N-Gain. The t-test was used to calculate the significance improved in collaborative skills, while N-Gain was to determine the degree of improvement in collaborative skills.

A paired t-test requires the data to be normally distributed. The normality test was carried out using the IBM SPSS 25 application with the Shapiro-Wilk formula. Based on the normality test results using the IBM SPSS 25 the results of the sig value. The pre-test value of class 5A was 0.452 and the post-test value was 0.261 . Meanwhile, the pre-test sig value of class 5B was 0.201 and the post-test score was 0.125 . Finally, the normality test of class $5 \mathrm{C}$ showed that the .sig pre-test was 0.448 and the .sig post-test was 0.125 . The result of sig.> 0.05 shows that the pre-test and post-test data for classes 5A, 5B, and 5C were normally distributed. Hence, the ttest analysis could be carried out to see whether there was a significant increase in collaborative skills. The results of the paired t-test are presented in the Table 1 below.

Table 1. Paired T-test Result

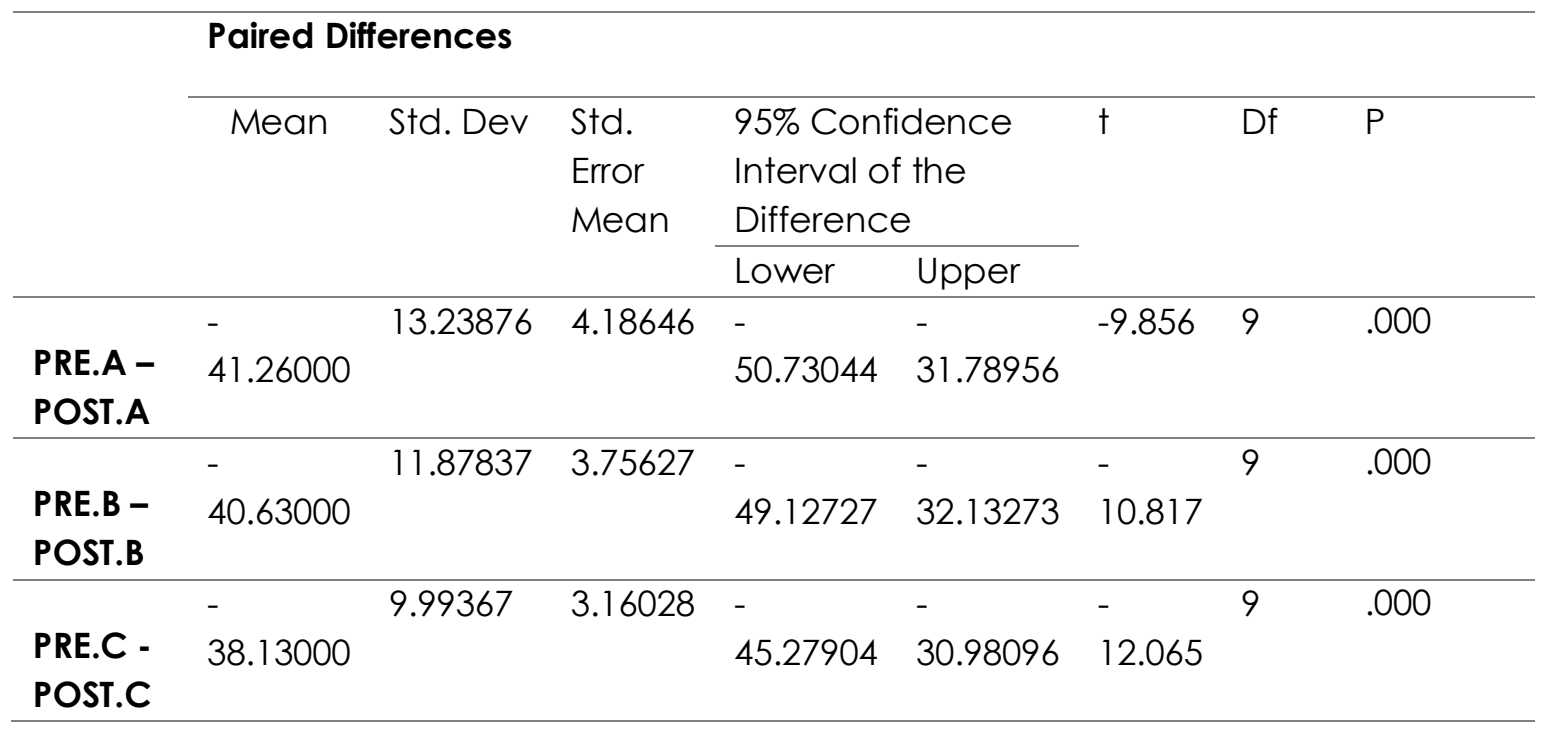

The t-test results obtained from the pre-test and post-test data for each of the 10 students in the classes $5 \mathrm{~A}, 5 \mathrm{~B}$, and $5 \mathrm{C}$ showed that the $\mathrm{P}$ value was 0.000 . Because the $P$ value $<0.05$, it 
Ishmatun Naila, The Effectiveness of Science Project Learning based on Entrepreneurship Model...

can be seen that there was a significant difference between the pre-test and post-test scores.

The degree of influence of learning effectiveness can be analyzed using the N-Gain formula. $\mathrm{N}$-Gain or the degree of improvement in several indicators of collaborative skills of students in class $5 \mathrm{~A}$ is presented in Table 2 below.

Table 2. N-gain Score of Collaborative Skills of 5A Students

\begin{tabular}{|c|c|c|c|c|c|}
\hline Number & Indicators & Pre-test & Post-test & $N$-Gain & Category \\
\hline 1. & $\begin{array}{l}\text { Be actively involved in } \\
\text { group discussions } \\
\text { (contribution aspect) }\end{array}$ & 40 & 87.5 & 0.8 & High \\
\hline 2. & $\begin{array}{l}\text { Give friends the } \\
\text { opportunity to express } \\
\text { opinions / ideas (aspects } \\
\text { of working effectively in } \\
\text { diversity of members) }\end{array}$ & 45 & 82.5 & 0.7 & High \\
\hline 3. & $\begin{array}{l}\text { Share tasks with each } \\
\text { other to achieve learning } \\
\text { goals (contribution } \\
\text { aspect) }\end{array}$ & 40 & 87.5 & 0.8 & High \\
\hline 4. & $\begin{array}{l}\text { Give ideas to solve } \\
\text { problems (problem } \\
\text { solving aspects) }\end{array}$ & 45 & 80 & 0.6 & High \\
\hline
\end{tabular}

Based on Table 2, it can be inferred that although the N-Gain on each indicator varies with a range between $0.6-0.8$. The category of improvement of collaborative skills for each indicator was the same, namely the high category.

As for the degree of improvement ( $\mathrm{N}$-Gain) several indicators of collaborative skills of class 5B students is presented in Table 3 below.

Table 3. N-gain Score of Collaborative Skills of 5B Students

\begin{tabular}{|c|c|c|c|c|c|}
\hline Number & Indicators & Pre-test & Post-test & N-Gain & Category \\
\hline 1. & $\begin{array}{l}\text { Be actively involved in } \\
\text { group discussions } \\
\text { (contribution aspect) }\end{array}$ & 40 & 80 & 0.7 & High \\
\hline 2. & $\begin{array}{l}\text { Give friends the } \\
\text { opportunity to express } \\
\text { opinions / ideas (aspects } \\
\text { of working effectively in } \\
\text { diversity of members) }\end{array}$ & 42.5 & 82.5 & 0.7 & High \\
\hline 3. & $\begin{array}{l}\text { Share tasks with each } \\
\text { other to achieve learning } \\
\text { goals (contribution }\end{array}$ & 40 & 80 & 0.7 & High \\
\hline
\end{tabular}



aspect)
Give ideas to solve
4. problems (problem
47.5
90
0.8
High
solving aspects)

In class 5B the degree of improvement of several indicators varies, with a range between 0.7 0.8 but all are in the high category, while for $\mathrm{N}$-Gain class $5 \mathrm{C}$ is presented in Table 4 . The data in Table 4 shows that the class $5 \mathrm{C}$ also had N-Gain variations with a range between $0.6-0.8$ with the high category.

Table 4. N-gain Score of Collaborative Skills of5B Students

\begin{tabular}{clllll}
\hline Number & $\begin{array}{l}\text { Indicators } \\
\text { 1. }\end{array}$ & Pre-test & Post-test & N-Gain & Category \\
\hline $\begin{array}{l}\text { Be actively involved in } \\
\text { group discussions } \\
\text { (contribution aspect) }\end{array}$ & 45 & 80 & 0.6 & High \\
\hline $\begin{array}{l}\text { Give friends the } \\
\text { opportunity to express } \\
\text { opinions / ideas (aspects } \\
\text { of working effectively in } \\
\text { diversity of members) }\end{array}$ & 47.5 & 87.5 & 0.8 & High \\
$\begin{array}{l}\text { Share tasks with each } \\
\text { other to achieve learning } \\
\text { goals (contribution } \\
\text { aspect) }\end{array}$ & 47.5 & 85 & 0.7 & High \\
\hline $\begin{array}{l}\text { Give ideas to solve } \\
\text { problems (problem } \\
\text { solving aspects) }\end{array}$ & 50 & 87.5 & 0.8 & High \\
\hline
\end{tabular}

After the N-Gain analysis was carried out, the pre-test and post-test data of all students were tested using one-way analysis of variance (one-way Anova) using the IBM SPSS 25 application to find out whether there was a difference in the average in the pre-test and post-test results done in classes 5A, 5B, and 5C. One-way analysis of variance data is presented in Table 5.

Table 5. One-way analysis of Variance Result

\begin{tabular}{ll|l|l|l|l} 
& $\begin{array}{l}\text { Sum of } \\
\text { Squares }\end{array}$ & df & $\begin{array}{l}\text { Mean } \\
\text { Square }\end{array}$ & F & Sig. \\
\hline $\begin{array}{l}\text { Between } \\
\text { Groups }\end{array}$ & 24187.813 & 5 & 4837.563 & 44.648 & .000 \\
\hline Within Groups & 5850.786 & 54 & 108.348 & & \\
\hline Total & 30038.599 & 59 & & & \\
\hline
\end{tabular}


Ishmatun Naila, The Effectiveness of Science Project Learning based on Entrepreneurship Model...

From Table 5 above, it can be inferred that the sig value was 0,000 , which means that there was a difference in the average pre-test and post-test scores for fifth grade students because (.sig) <0.05. In this process, students adapted to science project learning with an entrepreneurship approach in several learning meetings until their learning interests emerge and can improve their collaborative skills. According to Bruner (in Takaya, 2008), knowledge will be a compilation obtained from independent efforts obtained and seeking knowledge that supports it. In Bruner's theory, the teacher helps as a facilitator and guides to students in developing their knowledge independently.

\section{Results of Collaborative Skills Self-Assessment Sheet}

The analysis of the results of collaborative skills was obtained from the questionnaire, which amounted to 16 questions that refer to the indicators of collaborative skills. The results of the answers to the student questionnaires for classes $5 \mathrm{~A}, 5 \mathrm{~B}$, and $5 \mathrm{C}$ are presented in Table 6.

Table 6. Students Questionnaires' Answer

\begin{tabular}{lllllll}
\hline Aspects & \multicolumn{1}{l}{ 5A } & 5B & \multicolumn{2}{l}{ 5C } \\
\cline { 2 - 7 } & $\begin{array}{l}\text { Average } \\
\text { Percentage (\%) }\end{array}$ & \multicolumn{2}{l}{$\begin{array}{l}\text { Average } \\
\text { Percentage (\%) }\end{array}$} & \multicolumn{2}{l}{$\begin{array}{l}\text { Average } \\
\text { Percentage (\%) }\end{array}$} \\
\cline { 2 - 7 } & Yes & No & Yes & No & Yes & No \\
\hline Contribution & 92.5 & 7.5 & 87.5 & 12.5 & 85 & 15 \\
\hline Problem Solving & 85 & 15 & 77.5 & 22.5 & 80 & 20 \\
\hline $\begin{array}{l}\text { Working Effectively in } \\
\text { Diversity of Members }\end{array}$ & 92.5 & 7.5 & 87.5 & 12.5 & 92.5 & 7.5 \\
\hline Managing Projects & 92.5 & 7.5 & 95 & 5 & 85 & 15 \\
\hline
\end{tabular}

\section{Results of Collaborative Skills Observation}

Student collaborative skills in this study include four aspects, namely: contribution, problem solving, working effectively in diversity of members, and managing projects. Each aspect has indicators as presented in Table 6. Collaborative skills are observed by observers during learning. The results of the collaborative skills of students in classes $5 \mathrm{~A}, 5 \mathrm{~B}$, and $5 \mathrm{C}$ at the first, second, and third meetings during the trial are illustrated in Figure 1. 


\section{Collaborative Skills}

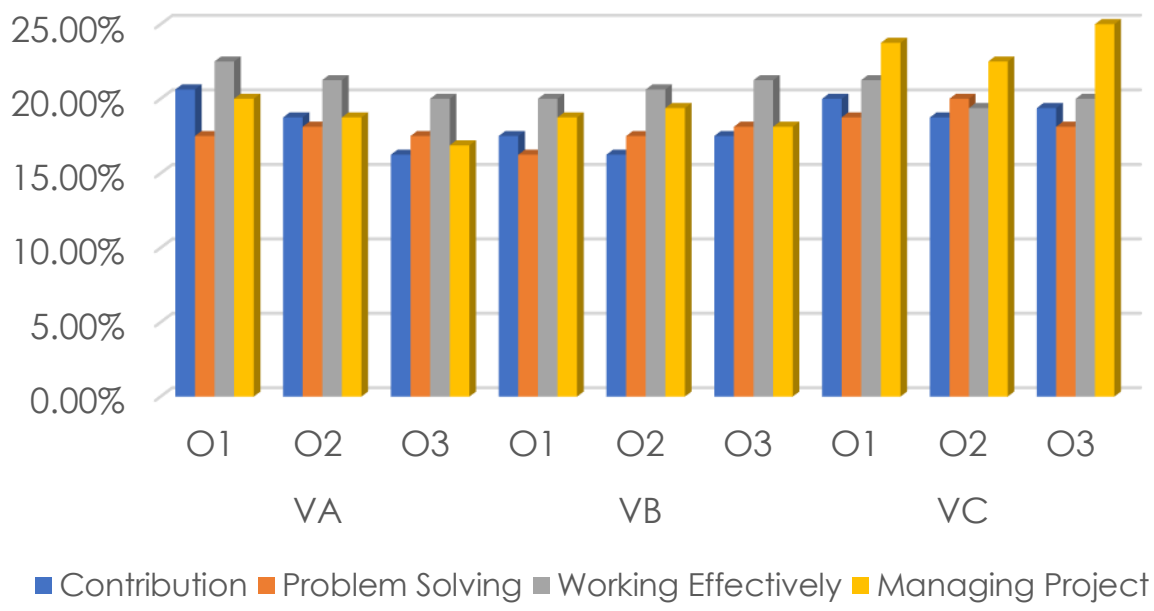

Figure 1. Observation in Students' Collaborative Skills

In class 5B, the percentage of collaborative skills that most often appeared was the aspect of working effectively in the diversity of members, while in class $5 \mathrm{C}$ the most frequently occurring collaborative skills were the aspect of managing projects. So based on Figure 1, it can be concluded that the most dominant skills during the application of science project learning with entrepreneurship-oriented were working effectively in diversity of group members and managing projects.

\section{DISCUSSION}

The effectiveness of learning model can be analyzed from the assessment of collaborative skills on test results, student activities, and student responses.

\section{Results of Collaborative Skills}

The collaborative skills test developed by the researcher consists of four description questions, each of which represents an indicator of collaborative skills and learning indicators. Based on the paired t-test analysis, it has been known that there was a difference between the results of the pretest and posttest before and after learning using entrepreneurship-oriented projectbased learning. Based on the results of the t-test, it turned out that project-based learning could significantly improve student collaborative skills. Data regarding the significance (.sig) of increasing collaborative skills were also in accordance with the results of the N-Gain calculation. The difference in the results before and after learning is presented in Tables 2, 3, and 4 showing $\mathrm{N}$-Gain for each indicator of collaborative skills. Based on the data, it can be inferred that the N-Gain of each indicator of collaborative skills of students in class 5A was in the high category, in class 5B was in the high category, and in class 5C the N-Gain value of 
Ishmatun Naila, The Effectiveness of Science Project Learning based on Entrepreneurship Model...

each indicator was also in the high category. In general, collaborative skills have experienced a high increase.

In addition to the improvement of each indicator, there was an increase in collaborative skills for each student. The N-Gain data for the collaborative skills of students in classes 5A, 5B, and $5 \mathrm{C}$ were then compared using a one-way analysis of variance formula (one-way ANOVA). Based on Table 5, the results of the analysis show that the sig value was 0.000 which indicates that was is a difference in the average result of increasing collaborative skills in the $5 A, 5 B$, and $5 \mathrm{C}$ because .sig $\geq 0.05$. Thus, in terms of increasing collaborative skills, in general, science project learning with entrepreneurship approach can be said to be effective. This is in accordance with Song (2018) that project-based learning can improve students' collaborative skills.

In their book, Trilling \& Fadel (2010) reveal that based on research, project-based learning was an effective learning model for practicing $21^{\text {st }}$ Century skills, especially collaborative skills because in project-based learning students can learn more deeply when they apply knowledge from learning in the classroom and implement it in the real-world problems. This theory is in accordance with Paschalis' research (Paschalis, 2017), stating that project-based learning was very suitable to improve students' collaborative skills. Collaborative project learning that can trigger students to be active in the learning process (Murawski, 2010).

Collaborative skills are the interaction of two or more professionals who work together to achieve goals. Not all learning processes will be compatible with the application of collaborative learning methods because not all activities can be carried out collaboratively, depending on the goals to be achieved. Collaborative learning is developed to improve or complement and support other learning models. Therefore, project-based learning is suitable for improving collaborative skills because every step in its activities requires collaborative between students in groups.

The results of increased collaborative skills are related to student activity and were. Students were very active when doing project-based learning and they are also enthusiastic in doing experimental activities carried out in groups. Student responses in learning obtained from questionnaires at the end of the lesson also showed positive results.

\section{Results of Self-Assessment Collaborative Skills (Student Response)}

Table 6 presents the results of student responses on their ability to perform collaborative skills. In the aspect of contribution, there were $92.5 \%$ students of class $5 \mathrm{~A}, 87.5 \%$ students of class $5 \mathrm{~B}$, $85 \%$ students of class $5 \mathrm{C}$ had done collaboration. In the problem-solving aspect, $85 \%$ students of class $5 \mathrm{~A}, 77.5 \%$ students of class $5 \mathrm{~B}$, and $80 \%$ students of class $5 \mathrm{C}$ had performed problemsolving activities. In the aspect of working effectively in the diversity of members, $92.5 \%$ 
students of classes $5 \mathrm{~A}$ and $5 \mathrm{C}$, and $87.5 \%$ students of class $5 \mathrm{~B}$ had done this aspect. Whereas, in the aspect project management, $92.5 \%$ students of class $5 \mathrm{~A}, 95 \%$ students of class $5 \mathrm{~B}$, and $85 \%$ students of class $5 \mathrm{C}$ had performed project management activity.

\section{Observation Results of Collaborative Skills (Student Activities)}

The observation results of the class $5 \mathrm{~A}$ and $5 \mathrm{~B}$ collaborative skills at the first, second, and third meetings showed that working effectively in diversity of members was the most frequently emerging skill. Whereas, in class 5C, the most common aspect was managing projects. From the observations it can be concluded that the most salient aspects were working effectively in diversity of members and managing projects.

$21^{\text {st }}$ century skills including collaborative skills in science classes can be trained during learning using project-based learning. This is consistent with research conducted by Rubrica (2018) who has proven the effectiveness of project-based learning as a more effective method of teaching.

\section{CONCLUSION}

Based on the aforementioned research findings, data analysis, and discussion associated with the problem formulation and research objectives, it can be concluded that the science project learning model meets the eligibility criteria, namely valid, practical, and effective. The learning model met the requirements for effectiveness, in terms of (1) enhancement of student collaborative skills was high; (2) well performance of collaborative skills well; (3) students' positive responses .

The proposed recommendation for the teacher is to understand and prepare the materials appropriately before implementing the science project learning model. In addition, the students must be accustomed to carrying out an investigative activity in science material, so that they are more confident in solving problems collaboratively by doing contribution, working effectively, and managing projects.

\section{ACKNOWLEDGMENTS}

Author would like to thank all the parties supporting this research. First, to the Rector of Muhammadiyah University Surabaya. Dr. dr. Sukadiono, M.M. for the chance given to us for doing this research. Second, to the Headmaster of Muhammadiyah 4 Surabaya Elementary School and all teachers in 5th grade who helped completing this research. Third, Prof. Dr. Budi Jatmiko and Dr. Elok Sudibyo for supervising the paper. 
Ishmatun Naila, The Effectiveness of Science Project Learning based on Entrepreneurship Model...

\section{REFERENCES}

Astutik, S., \& Prahani, B. K. (2018). The Practicality and Effectiveness of Collaborative Creativity Learning (CCL) Model by Using PhET Simulation to Increase Students' Scientific Creativity. International Journal of Instruction, $11(4)$, 409-424. https://doi.org/10.12973/iji.2018.11426a

Cho, Y. H., \& Lim, K. Y. T. (2017). Effectiveness of collaborative learning with 3D virtual worlds. British Journal of Educational Technology, 48(1), 202-211. https://doi.org/10.1111/bjet.12356

Fraenkel, W., Wallen, N., \&Hyun,H. (2012). How to design and evaluate research in education. New York: McGraw-Hill.

Fuad, A. Z., Alfin, J., Fauzan, F., Astutik, S., \& Prahani, B. K. (2019). Group Science Learning model to improve collaborative problem solving skills and self-confidence of primary schools teacher candidates. International Journal of Instruction, 12(3), 119-132. https://doi.org/10.29333/iji.2019.1238a

Ghazi, S. R., Ullah, K., \& Jan, F. A. (2016). Concrete operational stage of Piaget's cognitive development theory: An implication in learning mathematics. Gomal University Journal of Research, 32(1), 9-20. https://doi.org/10.5901/mjss.2011.v2n3p531

Gu, X., Chen, S., Zhu, W., \& Lin, L. (2015). An intervention framework designed to develop the collaborative problem-solving skills of primary school students. Educational Technology Research and Development, 63(1), 143-159. https://doi.org/10.1007/s1 1423-014-9365-2

Guthrie, C. (2014). The digital factory: a hands-on learning project in digital entrepreneurship. $\begin{array}{lll}\text { Journal of Entrepreneurship 115-133. } & \text { Education, 17(1), }\end{array}$ https://doi.org/10.4324/9780429506567-1

Harms, R. (2015). Self-regulated learning, team learning and project performance in entrepreneurship education: Learning in a lean startup environment. Technological Forecasting and Social Change, 100, 21-28. https://doi.org/10.1016/j.techfore.2015.02.007

Hassi, A. (2016). Effectiveness of early entrepreneurship education at the primary school level: Evidence from a field research in Morocco. Citizenship, Social and Economics Education, 15(2), 83-103. https://doi.org/10.1177/2047173416650448

Hermawan, H., Siahaan, P., Suhendi, E., Kaniawati, I., Samsudin, A., Setyadin, A. H., \& Hidayat, S. R. (2017). Desain Instrumen Rubrik Kemampuan Berkolaborasi Siswa SMP dalam Materi 
Pemantulan Cahaya [Instrument Design of Collaborative Ability of Junior High School Students on Light Reflection Materials]. Jurnal Penelitian \& Pengembangan Pendidikan Fisika, 3(2), 167-174. https://doi.org/10.21009/1.03207

Murawski, W. W. (2010). Collaborative teaching in elementary schools: making the coteaching marriage work! Corwin Press: California

Paschalis, G. (2017). A Compound LAMS-MOODLE Environment to Support Collaborative Project-Based Learning: A Case Study with The Group Investigation Method. Turkish Online Journal of Distance Education, 18(2), 134-150. https://doi.org/10.17718/tojde.306565

Polat, H. (2018). Analyzing Entrepreneurship Skill Levels of the 3rd Grade Primary School Students in Life Sciences Course Based on Different Variables. International Education Studies, 11 (4), 63-73. https://doi.org/10.5539/ies.v11n4p63

Putri, H. E., Rahayu, P., Muqodas, I., \& Wahyudy, M. A. (2020). The Effect of Concrete-PictorialAbstract (CPA) Approach on Improving Elementary School Students' Spatial Sense Ability. Mimbar Sekolah Dasar, 7(1), 119-132. https://doi.org/10.17509/MimbarSd.V7i1.19585.

Quint, J., \& Condliffe, B. (2018). Project-Based Learning: A Promising Approach to Improving Student Outcomes. Issue Focus. Mdrc, (January). Retrieved from www.mdrc.org. https://files.eric.ed.gov/fulltext/ED580907.pdf

Ramdan, M., Hanifah, N., \& Isrokatun, I. (2019). Situation-Based Learning Model Implementation through Thematic Learning as an Effort to Improve the Primary School Students' CPS Ability. Elementary School Forum (Mimbar Sekolah Dasar), 6(3), 304-316. https://doi.org/10.17509/mimbar-sd.v6i3.19075

Rubrica, R. D. B. (2018). An Action Research on Project-Based Learning and Understanding by Design and Their Effects on the Science Achievement and Attitude of Science Students. Journal of Education and Practice, 10(5), 24-44.. https://doi.org/10.7176/jep/10-5-02

Sabahi, S., \& Parast, M. M. (2020). The impact of entrepreneurship orientation on project performance: A machine learning approach. International Journal of Production Economics, 107621, 1-14. https://doi.org/10.1016/j.jppe.2020.107621

Seikkula-Leino, J., Ruskovaara, E., Ikavalko, M., Mattila, J., \& Rytkola, T. (2010). Promoting entrepreneurship education: the role of the teacher? Education+ Training, 52(2), $117-$ 127. https://doi.org/10.1108/00400911011027716 
Ishmatun Naila, The Effectiveness of Science Project Learning based on Entrepreneurship Model...

Shepherd, D. A., Haynie, J. M., \& Patzelt, H. (2013). Project failures arising from corporate entrepreneurship: Impact of multiple project failures on employees' accumulated emotions, learning, and motivation. Journal of Product Innovation Management, 30(5), 880-895. https://doi.org/10.1111/jpim.12035

Shum, K., Kodama, F., \& Shibata, T. (2020). Towards a Longitudinal Outlook on Industry Transition Management. Journal of Open Innovation: Technology, Market, and Complexity, 6(3), 79. https://doi.org/10.3390/joitmc6030079

Skiba, D. J. (2012). Disruption in higher education: Massively open online courses (MOOCs). Nursing Education Perspectives, 33(6), 416-418. https://doi.org/10.5480/1536-502633.6.416

Song, Y. (2018). Improving primary students' collaborative problem solving competency in project-based science learning with productive failure instructional design in a seamless learning environment. Educational Technology Research and Development, 66 (4), 9791008. https://doi.org/10.1007/s1 1423-018-9600-3

Takaya, K. (2008). Jerome Bruner's theory of education: From early Bruner to later Bruner. Interchange, 39(1), 1-19. https://doi.org/10.1007/s10780-008-9039-2

Trilling, B., \& Fadel, C. (2010). 21st century skills: Learning for life in our times. Teacher Librarian, 37(4), 47-5788. https://doi.org/10.5860/choice.47-5788

Yonanda, D. A., Yuliati, Y., \& Saputra, D. S. (2019). Development of Problem-Based Comic Book as Learning Media for Improving Primary School Students' Critical Thinking Ability. Elementary School Forum (Mimbar Sekolah Dasar), 6(3), 341-348. https://doi.org/10.17509/mimbar-sd.v6i3.22892 